\title{
LEGAL AND INSTITUTIONAL FRAMEWORK FOR SAFETY AND HEALTH AT WORK IN THE REPUBLIC OF NORTH MACEDONIA
}

\author{
Andon Majhosev ${ }^{1}$, Vera Paraklieva ${ }^{2}$ \\ ${ }^{1,2}$ Faculty of Law within the University "Goce Delcev" in Stip, Macedonia \\ andon.majhosev@ugd.edu.mk, vera_paraklieva@yahoo.com
}

\section{Original Scientific Paper doi:10.5937/jouproman7-21113}

\begin{abstract}
The safety and health at work are the unbreakable part of the work process. The International labour organization determined the safety and health at work as the primary international labour standard, and the Labour Law, as legal discipline, considers the safety and health at work as one of the basic legal principles within the labour relations.
\end{abstract}

This work will analyze the provisions of the most important state acts referring to the safety and health at work, especially the Constitution, the Labour Relations Law and the Law on safety and health at work. In addition, this work will also analyze the provisions of several collective contracts in order to determine whether and in what manner this matter has been regulated.

This work will also comprise the institutional establishment of the safety and health at work in the country.

Key words: regulation, institutions, safety, health, work

\section{Concept and definition of safety and health at work}

Speaking about the protection and safety at work, we actually refer to the working conditions and the work position itself. The life and health of each employee is a very important issue within the work process, since the employees spent eight hours per day at work. Depending on the work position, the employees are exposed to different dangers to their lives and health. Thus, the principle human right of righteous and suitable work conditions must be obeyed and it should represent a responsibility and obligation of the entire society.

In theory, there is a notion that the safety and health at work is an interdisciplinary concept for providing welfare to the people involved in the work process. At the same time, it provides protection for the employers from unanticipated and uncontrolled economic and material losses accrued from accidents caused by inapplicability of the safety and health at work measures.

According to the International Labour Organization, the safety and health at work generally aims at:

- Improvement and sustainability of highest level of physical, mental and social welfare for the workers from all occupations;

- Protection of the health and the workers related to the work conditions; 
- Protection of the employees at work from the risks accrued from health detrimental factors;

- Appointing the employees and protection of their integrity within the working environment, adapting to their physical and mental capabilities;

- The work should be adjusted to the people.

The basic principles and norms related to safety and health at work should be included in the national legislation of each country member of the International Labour Organization

\section{Legal framework for safety and health at work in RM}

A very important element in the system entitled safety and health of the employees at work is the legal regulation. The legal regulation in this area in the Republic of Macedonia is based on the international - legal instruments of the United Nations, International Labour Organization, European Council and European Union. This implies that the Republic of Macedonia has implemented those instruments in the national labour legislation, which is the basic prerequisite for our further integration in the international community, especially EU.

The Republic of Macedonia employees realize their right of safe and healthy working environment pursuant the RM Constitution, the Labour Law (Official Gazette of RM no. 62/05), the Law on
Safety and Health at Work (Official Gazette of RM no.92/07) and other laws related to labour, bylaw acts - rulebooks, as well as collective contracts.

The right to healthy and safe working environment is guaranteed by the Constitution of the country, thus it is a constitutional category. The right of healthy and safe working environment is explicitly clarified in Article 32 of the RM Constitution, stating the following: "Everybody has the right to work, the right of free employment choice, and safety at work..."1 and this right implies incorporation of rights and obligations by the employees as well as the employers.

The employer is obliged to guarantee safety at work to the employee, providing the necessary condition for that safety, pursuant the Law on Labour Relations (Official Gazette of RM no. $62 / 05$ ). If the employer does not provide conditions for safety of the employees' life and health, the law prescribes penalty provisions.

The employee, engaged to definite or indefinite time, irrespectively, should realize its right to safety at work pursuant the prescribed measures and norms, identified for that safety, pursuant the law and the collective contract.

The employee is obliged to follow the prescribed conditions and measures for safety at work (article 32 of the Law on Labour Relations). In that respect, the employees are obliged to perform their work carefully, in order to protect their lives and health as well the lives and health of the other employees, and the citizens in general.

\footnotetext{
${ }^{1}$ Article 32, paragraph 1 of the RM Constitution
} 
If the employees do not follow the prescribed safety and health measures, or do not use the work means and equipment properly and according to the anticipated regulation, pursuant the Law on Labour Relations, this is considered as violation of the work discipline or breach of conditions determined by law, collective contract of employment agreement, thus resulting in termination of the labour relation, dismissal by the employer without any notice (Law on Labour Relations, article , paragraph , item ). This provision of the Law has been included in all special (branch) collective contracts with retained certain specifics of the particular activity.

The Law on Records related to labour was brought in 2004. The primary purpose of the law is to keep records of the work place accidents. Pursuant the provision of this law, the records related to the labour should be kept as obligatory records of employees' accidents at work.

The accidents at work records contain data entered within three days as of the accident.

Besides data related to the injured employee, the records contain data related to the injury. The following is the data related to the injuries:

1) The work the employee was performing at the time of the injury at work;

2) How many hours has the employee been working on the day of the injury;

3) Has the employee been injured before;

4) The type of injury;

5) Injured part of the body;

6) Was the injury fatal;

7) Basis for insurance.
The following is the data related to the injury at work: 1) When did the accident take place (day, month, year, week day, time of the day); 2) Where did the accident take place (at the place of performing the work tasks, while commuting to work or vice versa, at a business trip); 3) How many people had been injured at work; 4) How many people died at the accident, or on the way to the health organization; 5) Has there been any similar accident at the same work position or the same work; 6) The origin of the accident; 7) Causes of the accident; 8) Utilization of personal safety means; 9) Had it been determined that the employee was in jeopardy. ${ }^{2}$

The abovementioned data from the records will provide a clear image about the injuries of the employees at the time of work, which will contribute to recognizing the errors and imperfections at work positions, and their reduction, thus decreasing the injuries and accidents at work.

\section{The Agreement for Establishment} of Economic Social Council of RM states the following:

"The Republic of Macedonia
Government, the Trade Union and the
Chamber of Commerce of Macedonia are
establishing the Economic and Social
Council 3 in order to realize the
fundamental values of the Republic of
Macedonia Constitution for democratic
and social country and assurance of social
justice for more harmonious development
of the social processes, for improvement of
the social dialog, tripartism and
application of the international conventions
and recommendations.

\footnotetext{
${ }^{3}$ See Article 1 of the Agreement for Establishing an Economic - Social Council of RM
}

${ }^{2}$ Law on Records related to labour, Article 25 of
the Official Gazette of RM no 16/04; 
The Council has its advisory consultative function implementing the social dialog and considerable part of the negotiating function of the social partners for economic-social issues of interest for the Republic of Macedonia. ${ }^{4}$

Pursuant these functions, the Council takes into consideration issues and gives opinions related to certain issues from the area of work conditions and safety at work. $^{5}$

\section{Analysis of the provisions from the Law on Safety and Health at Work}

The Law on Safety and Health is lex specialis for this area. Taking into consideration the enormous importance of the Law on Safety and Health at Work (Official Gazette of RM no.92/07) we consider that it is necessary to elaborate this law. The Law is consisted of 67 articles comprised in IX chapters. The law determines the safety and health at work measures; the general and other responsibilities of the employer; the rights and obligations of the employees within the area of safety and health at work; the role of the employees' representative; preventive measures against professional risks; removal of the risk factors within accidents; notification and consultation with the social partners about the safety and health of the employees; records and reports; employees' training; establishment and functioning of the Safety and Health at Work Council; authorization; supervision; misdemeanor provisions.

\footnotetext{
${ }^{4}$ See Article 1 of the Agreement for Establishing an Economic - Social Council in RM
}

\section{A) Employer's responsibilities}

The Law on Safety and Health at Work defines the General and other responsibilities of the employer, according to which the employer is responsible to:

1. Prepare a risk assessment for every work position

2. Prepare and conduct a Declaration for safety for every work position, specifying the manner, necessary measures based on the identification of the danger from the risk assessment

3. Appoint one or more qualified persons for safety at work, with vocational training for safety at work, or other professional training suitable within the technological process

4. Engage authorized health organization that practices labour medicine

5. Follow the health condition of the employees (the employer should organize health examinations for the employees every 18 months)

6. Provide safety measures against fire pursuant the special principles

7. Organize and provide first aid to the employees in case of accidents at work

8. Establish an evacuation and rescue plan in case of danger, first aid, as well as to provide practical training at least once in two years

\footnotetext{
${ }^{5}$ See Article 3, paragraph 2, line 7 of the Agreement for Establishing Economic - Social Council in RM dated on December 30, 1996
} 
9. Every work position and work premises with 20 employees should have at least one person trained and appointed to give first aid, extinguish fire, evacuate or rescue and it there are more than 20 employees, there should be one such person for every 20 employees.

10. Make contracts with other legal entities specialized in providing services related to first aid, urgent medical care, evacuation and rescue and fire prevention.

11. Perform theoretical and practical training of the employees for safe performance of the work before appointing them on the work position, during transfer from one to another work position, while altering the instruments for work, or the technological process etc.

12. Provide personal protective equipment for the employees (equipment the employees wear, keep and use).

13. Perform periodical exams and analysis of the working environment and equipment in the manner and time limits prescribed by the act, i.e. the instruction of the manufacturer, technical regulations an standards

14. Keep records about the professional training and qualification of the employees for safer work, the performed examinations of the employees for safer work, performed analysis related to the means of work, the conducted examinations of the physical, chemical and biological hazards of the microclimate within the working and subsidiary premises, previous and periodical health exams of the employees, professional diseases, diseases related to the work, injuries at work and cases of death at work.

15. The employer is obliged to provide the safety and health at work representative with continuous performance of the their function.

\section{B) Rights and obligations of the employees}

The rights and obligations of the employees in the company related to the safety and health at work are regulated by Articles 38 - 42 of the Law on Safety and Health at work. The following are the rights and obligations:

- The employee has the right and responsibility to participate in the determination and improvement of the work conditions and work environment, to propose taking new or improving the current measures for safety and health at work, organization of the work and protection of the employees' health and safety within the work process;

- The employee is obliged to follow the measures and means for safety and health at work during working hours and to perform the work carefully, in order to provide and take care of their health, as well as the life and health of the other employees and to cooperate with the employer while conducting and improving the safety and health at work. 
- Pursuant the employer's act and the collective contract, the employee who does not follow the measures and means imposed by the law, thus endangering their and the life of the other employees, the employer's property and the environment and nature, can be temporarily suspended from the work position, and the employees' representative of safety and health at work will be notified about the suspension in writing. The employee who does not follow the imposed safety and health measures, other principle and collective contract, causes serious nonobservance of the work responsibility.

- The employee is obliged to report all observed defects and other imperfections and occurrences, which directly imperil the safety of the employees at work and has the right to request undertaking suitable measures for safety and health at work.

- Provided that the employer does not undertake other measures for resolving the defects and other imperfections and occurrences that directly imperil the safety at work, the employees safety and health at work representative can require termination of work at certain time of part of the technical technological process, or the complete performance and will inform the employer regarding the reasons, time and place of the termination in writing. The employer is obliged to notify the administration body authorized for the labour inspection matter about the situation immediately.

- The employee has the right to refuse performance of any activity on their work position, if there is certain direct danger threatening their life and health, as a result of not conducting the anticipated measures for safety and health at work, until the reasons infringing the safety are resolved. The employee can refuse to work on an instrument without the anticipated safety devices. The employee has the right to refuse working on the position where there is a risk of professional or other diseases. The employee is obliged to notify the employer and the representative for safety and health at work regarding the reasons for their rejection to work.

The employer is obliged to take measures for resolving the reasons that directly endanger the life and health of the employees at work.

\section{C) The role of the employees representative for safety and health}

The rights and obligations of the representative for safety and health at work are regulated by articles 28, 29 and 30 . Pursuant those articles, the employees' representative for safety and health at work is chosen by the employees, at a syndicate's conference, or employees conference, taking into consideration the inclusion of all parts of the working process and compulsory for those necessary by the work conditions (increased danger of the safety and health of the employees, performance on certain location etc.). 
The employees' representative, as well as the representative of the syndical organization, has special protection within the performance, pursuant the law and the collective contract. The number of representatives depends on the number of employees, where as:

- One representative for more than 10 employees;

- Two representatives for 101 - 500 employees;

- Three representatives at employers that have more than 501 employees;

- The employees' representative for safety and health at work has the right to:

- visit the work positions in order to observe the condition related to safety and health at work

- discuss the needs and problems related to the safety and health at work with the employer

- notify the labour inspection and ask for their direct intermediation or supervision

- notify the labour inspection about their intermediation, to attend, give their perceptions and to have an insight in the report prepared by the inspectorate about the intermediation, or supervision.

- ask for information from the employer and have an access to the statements about the assessment of safety and health at work

- receive special training for prevention and safety and health at work, specific for the employer's activity determined by a collective contract.

\section{D) Supervision of the Law}

The Ministry in jurisdiction for labour matters performs supervision over the implementation of the Law on Safety and Health at Work, and the labour inspection within the area of safety and health at work is performed by the State Labour Inspectorate pursuant the Law on Safety and Health at Work and the Law on Labour Inspection.

\section{Institutional framework for safety and health at work}

The most important institutions that have competence for improving the conditions for safety and health at work are The Council for safety and health at work and the Labour inspection.

\section{The Council for safety and health} at work: The Republic of Macedonia government established the Council for safety and health at work, as well as an expert advisory body that takes into consideration and gives opinion and recommendation regarding the following: The Program, condition related to the safety and health at work, strategy for coherent politics for prevention and reduction of the injuries at work, professional and other diseases and injuries related to the work, expert fundamentals for preparation of laws and other principles for safety and health at work, and documents for international organizations referring to the safety and health at work (article 43 of the Law on Safety and Health at Work). 
The Council is consisted of 15 members, four of which are from the representative employers' organizations, four from the representative syndicates, three are appointed by the Government of the Republic of Macedonia, one member is a representative of the faculty that conducts educational activity within the area of safety at work, one member is representative of the faculty that provides educational activity within the area of labour medicine, and one member is representative of the association of labour medicine (Article 44, paragraph 1).

The appointing of Council members should be conducted taking into consideration the principle for objective and adequate prevalence of all communities in the Republic of Macedonia, not infringing the principle of professionalism and competence (Article 44, paragraph 2).

Labour inspection: The greatest part of the responsibility regarding the application of protection and safety at work belongs to the labour inspection. The labour inspection functions within the Ministry of Labour and Social Policies as autonomous and independent body. Pursuant the Law on Labour Inspection, it is anticipated that the labour inspection over the application of laws and other principles related to the labour and employment should be performed by the labour inspection (Article 1). Article 4 provides that the labour inspection, as an administrative body within the Ministry of Labour and Social Policies, should conduct the measures related to labour and protection at work.

Consequently, labour inspection is present in all normative acts regulating issues

\footnotetext{
${ }^{6}$ See Article 3 of the Agreement for establishing Economic - social Council.
}

related to protection at work within provision of supervision over the implementation of health protection and safety at work.

The Law on Labour Relations anticipates that labour inspection should provide for the supervision and control over the conduction of its norms (Article 256).

Labour inspection is authorized to perform control and supervision over the application and following the provisions regulating the safety at work of special categories of employees. In addition, the inspection supervision refers to control of the employer's responsibilities, as well as the eventual employees' obligations (pursuant Article 256).

The Law on Safety and Health at Work also anticipates that the supervision should be made by the labour inspection (Article 48). If the supervision made by the inspector perceives shortcomings endangering the health and safety of the employees, the inspector can make a decision to prohibit employer's work (Article 49, paragraph 2). This is especially important decision, since it provides to the special categories of workers direct protection by the labour inspection if their health or life (theirs or the life of the child at pregnant workers and mothers) is endangered without conducting procedures to the employer, or a court procedure).

The economic-social council of RM has advisory - consultative function used to perform the social dialog and the significant part of the negotiating function of the social partners for economic - social issues in RM. ${ }^{6}$ 
According to these functions, the Council discusses issues, gives opinions, suggestions and recommendations for certain issues related to the area of work conditions and safety at work. ${ }^{7}$

\section{Conclusions}

The labour (work) represents basis for provision of existence in the human life, thus it has significantly important role. One third of the day, the employees spend at work, facing multiple health risks from the working environment such as: dust, noise, chemical impact, extreme temperatures, vibrations etc. Most of the employees, unfortunately, are not aware about this problem; hence suffer certain consequences upon their health.

This is contributed by the employers (with small exceptions) that neglect the safety and health of the employees on account of making greater profit. Nevertheless, recently, employers became more aware that only good and healthy working environment could lead to the desired business success (results). ${ }^{8}$

Safety and health at work represent a priority issue for the employees, as well as the entire country, which can be perceived in the Strategy for Safety and Health at Work of RM. The right to safety and health at work is a fundamental work right. In order to realize this right, it is necessary to

\footnotetext{
${ }^{7}$ See Article 3, paragraph 2, line 7 of the Agreement for Establishing Economic - Social Council in RM dated on December 30, 1996.

8 The author of this paper visited a well-known confection in Shtip, renowned as well-organized regarding the safety and health conditions at work, and during the conversation with its manager about
}

apply the following measures and activities: Suitable application of the Law on safety and health at work; Efficient performance of the RM Safety and Health Council; Concluding collective contracts among the employers in order to regulate the issues referring to the safety and health at work; the employees who work at hazardous positions should be insured in specialized companies; the chosen employees representatives for safety and health at work should be educated permanently in order of early identification of the symptoms of any potential professional disease before it develops into a chronic illness; the Sector for safety and health at work within the Ministry of Labour and Social Policies as part of the State Labour Inspectorate should be enhanced with personnel in order of efficient performance, especially for supervision of the employers regarding the conditions for hygienic and technical conditions, preparations and submission of requests for misdemeanor and criminal procedures, recording the claimed injuries at work; establishing real social dialog between the syndicate, employers' organizations and the country regarding mutual and synchronized resolution of the issues related to safety and health at work; safety and health at work should be integrated in our educational system through adequate vocational subject and curriculum, thus providing the pupils with basic knowledge about this area since early age;

the employees work conditions, it was stated that better results were evident after establishing airconditioning of the working premises. In addition, the confection manager presented relevant data regarding the productivity of the employees after establishing better climate conditions that showed increase of $15-20 \%$. 
syndicates, professional organization and other similar associations should influence, through the media, the strengthening of the public awareness about the importance of the safety and health at work and the companies that engage more than 50 employees should be obliged to employ one expert who will provide for the safety and health of the employees at work.

\section{BIBLIOGRAPHY}

1. Bilikj, A and Bukuljash, (2006), International Labour Law, Split;

2. Action plan for conduction the Strategy for safety and health at work 2020, for 20172020;

3. European social document of the European Council 1961

4. Law on Labour Relations of RM (Official Gazette of RM no.62/05) and successive issues;

5. Law on Safety and Health at Work (Official gazette of RM no.92/07) and successive issues;

6. Law on Record referring to labour (Official Gazette of RM no.16/04) and all successive issues; Reports from the European Commission for 2006, 2007, 2008... year for the improvement of RM
7. Jovevski, L (2014), The system for protection of health and safety at work "ratione personae", Friedrich Ebert foundation, Skopje;

8. International labour standards (2007), Ratified conventions from RM, USAID and MLSP, Skopje;

9. International conventions of the International Labour Organization no.155 for safety and protection of health at work and the working environment.

10. Naumovski, P. (2007), Labour Law, European University, Skopje;

11. Guide (2009), "Mobing - psychological pressure at work place", Skopje;

12. Guide for safety and health at work (2008), Trade Union of Macedonia and Foundation Friedrich Ebert, Skopje;

13. Program for safety and health at work of the Republic of Macedonia Government (Official Gazette of RM, no. 115 dated on August 22, 2017);

14. Treaty for forming the Economic - social Council of RM dated on December 30, 1996

15. Starova, G (2003), Labour law and labour relations, Prosvetno delo, Skopje;

16. Strategy for safety and health at work of RM until 2020; (Official Gazette of RM, no. 115 dated on August 22, 2017);

17. RM Constitution, 1991

18. International Labour Organization Constitution

19. Philadelphia declaration of UN dated on June 10, 1944 